William Shearer FANZCA, John Monagle FANZCA, Morad Michaels FRACGP

\title{
A model of community based, preadmission management for elective surgical patients
}

\begin{abstract}
Purpose: This paper outlines the process of preadmission elective surgical preparation utilised at our institution.
Methods: The process commences with a health status questionnaire sent to all patients. Based on the results of the questionnaire all elective surgical patients are then triaged: (i) to be assessed by an appropriately accredited general practitioner ( $45 \%$ of elective surgical patients) and subsequently attend preadmission clinic; (ii) to be seen by an anaesthetist (25\%) and also be preadmitted at this visit or (iii) to go directly to preadmission clinic (30\%).

Results: This has resulted in a $96 \%$ same day admission rate for all elective surgery. Cancellations due to suboptimally prepared patients are $<1 \%$. The involvement of general practitioners in this process has reduced patient inconvenience. There has been marked improvement in the ability to admit patients on the same day of surgery for all types of surgery while minimising late cancellations. This has been achieved at a minimum real cost.

Conclusion: Preanaesthetic assessment is important for patient well-being and hospital throughput. We describe a system for utilising non-anaesthetist general practitioners in this process. Their familiarity with their own patients and appropriate training in preoperative assessment significantly contributes to the efficiency of our elective surgical throughput.
\end{abstract}

Objectif : Exposer le rôle de la préadmission en chinurgie élective d'un jour en vigueur dans notre institution.

Méthodes : Au départ, tous les patients répondent à un questionnaire sur leur état de santé. Sur la base des résultats de ce questionnaire, tous les candidats à une chirurgie non urgente sont dirigés : (i) vers un omnipraticien accrédité de la clinique de préadmission pour évaluation (55\% de tous les patients chirurgicaux électifs); (ii) vers un anesthésiste (25\%) pour préadmission ou (iii) directement vers la clinique de préadmission (35\%).

RÉsultats : Grâce à ce système, le taux d'admission le même jour pour toute la chirurgie non urgente a atteint $96 \%$. Les annulations dues à une préparation insuffisante sont inférieures à $1 \%$. Lintroduction des omnipraticiens dans ce système a réduit les inconvénients pour les patients. Ceci s'est manifesté par une amélioration de notre capacité d'admettre les patients le jour même de l'intervention pour tous les types de chirurgie tout en ramenant au minimum les annulations de demière heure. Ceci a été réalisé à bon prix.

Conclusion : L'évaluation préanesthésique est importante pour le patient et l'efficacité de l'hópital. Notre système utilise des omnipraticiens sans formation anesthésique. La connaissance intime de leurs patients et une formation appropriée en évaluation préopératoire contribuent de façon significative au rendement du programme de chirurgie élective.

From the Department of Anaesthesia and Dandenong Division of General Practice, Dandenong Hospital, David Street, Dandenong, Victoria, 3175 Australia.

Address correspondence to: Dr. W. Shearer, Department of Anaesthesia; Phone: 61-3-9797-8366; Fax: 61-3-9797-8590.

Accepted for publication 17 August, 1997. 


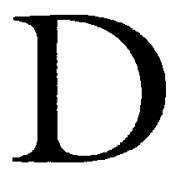

ANDENONG Hospital is a 280 -bed teaching hospital situated in the outer suburbs of Melbourne, Victoria, Australia. The hospital offers all surgical specialties except cardiac surgery and intracranial vascular surgery. Approximately 9,000 surgical procedures are performed each year. Sixty-five percent of these procedures are elective and thirty-five percent are classified as urgent or semi-urgent cases. The hospital does not maintain formal outpatient clinics and surgical cases are referred to the hospital from the private rooms of medical staff.

Before 1992 there was an ad hoc provision for the pre-operative assessment of elective surgical patients. Such patients as required optimisation before surgery were either seen in private rooms by consultant physicians or admitted up to three days prior to surgery for assessment and investigation by the visiting anaesthetic staff, as determined by the surgeon.

A new assessment system was initiated in 1992, and has continued to develop. This preoperative preparation system has altered the medical focus of preoperative assessment as well as increasing the efficiency of elective surgical throughput.

\section{Methods}

The current system of anaesthetic assessment involves the following steps (see Figure 1).

1. Request for elective surgical admission received by hospital (generated from private rooms of surgeon).

2. A health status questionnaire is sent to all elective surgical patients by the hospital.

3. The completed questionnaire is returned to the hospital by the patient. The General Practice (GP) Liaison Officer (A General Practitioner employed by the hospital as a link between the hospital and community based medical practitioners) assesses and triages the patients according to the questionnaire results.

4. Steps 1 to 3 must be completed before the patient is entered onto the hospital waiting list.

5. Patients are triaged to:

(i) hospital based preadmission clinic, or

(ii) an accredited general practitioners' rooms for preoperative assessment. (Preadmission occurs at a subsequent hospital visit), or

(iii) anaesthetic outpatients at the hospital to be reviewed by a consultant anaesthetist. (Preadmission occurs concurrently at this visit).

6. Step 5 is completed after the patient has been booked for surgery. The time between assessment and surgery is 2 to 4 weeks.
7. All patients see their attending anaesthetist after admission.

This approach developed as an alternative to the traditional approach of admitting patients several days prior to surgery, which is costly, inefficient and for the majority of patients unnecessary. ${ }^{1}$ Preadmission assessment by specialist anaesthetists for all patients was considered unachievable based on staff availability and funding in our institution. Questionnaires and phone calls have previously been shown to be useful. ${ }^{2}$ However, in the setting of adult patients with established disease that might require optimisation, a face to face interview and physical examination was considered the preferred approach. ${ }^{3}$

Previous experience with the preoperative referral pattern of surgeons locally and elsewhere ${ }^{1,4}$ in relation to preanaesthetic assessment led to the development of the preoperative questionnaire as the basis for our system. Triage of patients (Figure 2) is performed according to their age, the proposed surgery and by

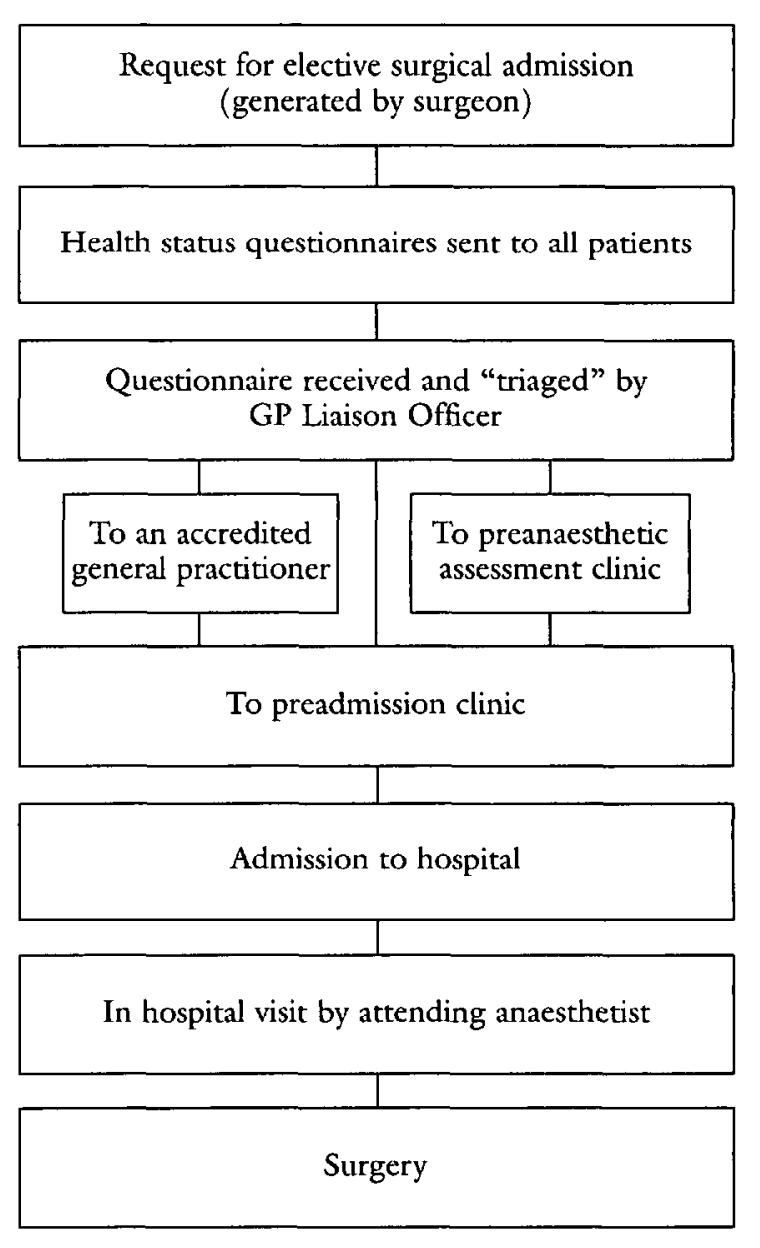

FIGURE 1 Steps involved in the preadmission process. 


\begin{tabular}{|c|c|c|c|}
\hline$A G E$ & OPERATION & ASA CLASSIFICATION & DESTINATION \\
\hline \multirow[t]{3}{*}{$<35 \mathrm{yr}$} & minor & $\begin{array}{c}1 \& 2 \\
3 \\
4\end{array}$ & $\begin{array}{c}\text { Preadmission } \\
\text { GP } \\
\text { PAAC }\end{array}$ \\
\hline & moderate & $\begin{array}{c}1 \& 2 \\
3 \\
4\end{array}$ & $\begin{array}{c}\text { Preadmission } \\
\text { GP } \\
\text { PAAC }\end{array}$ \\
\hline & major & $\begin{array}{c}1 \& 2 \\
3 \\
4\end{array}$ & $\begin{array}{c}\text { GP } \\
\text { PAAC } \\
\text { PAAC }\end{array}$ \\
\hline \multirow[t]{3}{*}{$35-50 \mathrm{yr}$} & minor & $\begin{array}{c}1 \& 2 \\
3 \\
4\end{array}$ & $\begin{array}{c}\text { Preadmission } \\
\text { GP } \\
\text { PAAC }\end{array}$ \\
\hline & moderate & $\begin{array}{c}1 \& 2 \\
3 \\
4 \\
\end{array}$ & $\begin{array}{c}\text { Preadmission } \\
\text { GP } \\
\text { PAAC }\end{array}$ \\
\hline & major & $\begin{array}{c}1 \& 2 \\
3 \\
4\end{array}$ & $\begin{array}{l}\text { GP } \\
\text { PAAC } \\
\text { PAAC }\end{array}$ \\
\hline \multirow[t]{3}{*}{$50-65 \mathrm{yr}$} & minor & $\begin{array}{c}1 \& 2 \\
3 \\
4\end{array}$ & $\begin{array}{c}\text { Preadmission } \\
\text { GP } \\
\text { PAAC }\end{array}$ \\
\hline & moderate & $\begin{array}{c}1 \& 2 \\
3 \\
4 \\
\end{array}$ & $\begin{array}{c}\text { GP } \\
\text { PAAC } \\
\text { PAAC }\end{array}$ \\
\hline & major & $\begin{array}{c}1 \& 2 \\
3 \\
4\end{array}$ & $\begin{array}{c}\text { GP } \\
\text { PAAC } \\
\text { PAAC }\end{array}$ \\
\hline \multirow[t]{3}{*}{$>65 \mathrm{yr}$} & minor & $\begin{array}{c}1 \& 2 \\
3 \\
4\end{array}$ & $\begin{array}{c}\text { GP } \\
\text { PAAC } \\
\text { PAAC }\end{array}$ \\
\hline & moderate & $\begin{array}{c}1 \& 2 \\
3 \\
4 \\
\end{array}$ & $\begin{array}{c}\text { GP } \\
\text { PAAC } \\
\text { PAAC }\end{array}$ \\
\hline & major & $\begin{array}{c}1 \& 2 \\
3 \\
4\end{array}$ & $\begin{array}{c}\text { GP } \\
\text { PAAC } \\
\text { PAAC }\end{array}$ \\
\hline
\end{tabular}

FIGURE 2 Algorithm for patient triage

estimating the patients ASA physical classification according to questionnaire results. A triage algorithm was developed locally based upon review of 1,500 patients who had completed questionnaires and subsequently undergone the traditional preoperative process. The GP Liaison Officer spent several weeks working with the full time anaesthetic department to develop consistency in classification.

\section{Results}

Thirty percent of all elective surgical patients are triaged to attend pre-admission clinic only.

Forty-five percent of patients are triaged to see an "accredited" GP. This will preferably be the patients regular GP if he/she has undergone the accreditation process. Accredited GPs have undertaken two workshops where they are informed by anaesthetists about 
the essentials of preoperative assessment and optimisation. There is a direct line of communication from the GPs to a consultant anaesthetist should further consultation or referral to the preanaesthetic assessment clinic be necessary.

Twenty-five percent of patients are triaged directly to see an anaesthetist.

\section{Discussion}

This process has facilitated $96 \%$ of elective surgical patients being admitted on the same day of surgery. Before institution of this process, $6 \%$ of patients admitted for elective surgery had preventable cancellations after admission, due to admission in suboptimal medical condition. At present, the rate of cancellation of elective surgical patients after admission is less than $1 \%$. Such improvements have been demonstrated elsewhere following the institution of pre-anaesthetic assessment clinics. ${ }^{1}$

A preoperative visit is performed by the attending anaesthetist on the day of surgery and is important for both patient care and patient satisfaction. ${ }^{5,6}$ However the anaesthetist can approach complicated medical patients undergoing same day surgical admission confident that elective surgical patients are being admitted to hospital in an optimal state, with relevant investigations and assessment to hand. Davis ${ }^{7}$ et al. in 1987 suggested that neither age nor ASA status form a contraindication to ambulatory surgery. Similarly, it has been our experience that neither age nor ASA status form a contraindication to same day admission for all types of surgery for patients who have been through an appropriate preoperative system.

There are several advantages to this system: (i) community practitioners and resources are more fully utilised; (ii) patients prefer to spend less time in hospital in the preoperative phase ${ }^{8}$ (iii) discharge planning can begin at the initial contact with the family practitioner; and (iv) there is a potential re-allocation of hospital resources.

This model has streamlined our preoperative management and admission system. There appears to have been a significant improvement in bed utilisation efficiency associated with a decrease in overall costs to the hospital. This has been demonstrated elsewhere. ${ }^{8}$ As the model continues to develop data to substantiate these impressions will need to be collected. Collection and interpretation of such data has proven difficult ${ }^{9}$ but is essential in the face of increasing economic pressure. When combined with the "perioperative system" of Kerridge et al. ${ }^{10}$ this model provides a community based focus of care for elective surgical patients.

\section{References}

1 Conway JB, Goldberg J, Chung F. Preadmission anaesthesia consultation clinic. Can J Anaesth 1992; 39: 1051-7.

2 Kleinfeldt AS. Preoperative phone calls. Reducing cancellations in pediatric day surgery. AORN J 1990; 51: 1559-64.

3 Roizen MF. Preoperative evaluation. In: Miller RD (Ed.). Anesthesia, 3rd ed. New York: Churchill Livingstone Inc., 1990: 743-72.

4 Goldberg J, Chung F, Conway J. Preadmission clinic (Letter). Can J Anaesth 1993; 40: 471-2.

5 Coben NH, Tschann JM, Adamson TE. Assessment of patient satisfaction with anaesthesia services. Anesth Analg 1988; 67: S34.

6 Farnill $D$, Inglis $S$. Patients desire for information about anaesthesia: Australian attitudes. Anaesthesia 1993; 48: 162-4.

7 Davis JE, Sugioka K. Selecting the patient for major ambulatory surgery. Surgical and anesthesiology evaluations. Surg Clin North Am 1987; 67: 721-32.

8 Rudkin GE, Bacon AK, Burrow B, at al. Review of efficiencies and patient satisfaction in Australian and New Zealand day surgery units: a pilor study. Anaesth Intensive Care 1996; 24: 74-8.

9 Boothe P, Finegan BA. Changing the admission process for elective surgery: an economic analysis. Can J Anaesth 1995; 42: 391-4.

10 Kerridge $R$, Lee A, Latchford E, Beehan SJ, Hillman $K M$. The perioperative system: a new approach to managing elective surgery. Anaesth Intensive Care 1995; 23 : 591-6. 